\title{
Topographic Position, Land Use and Soil Management Effects on Soil Organic Carbon (Vineyard Region of Niš, Serbia)
}

\author{
Snežana Jakšić ${ }^{1, *(D)}$, Jordana Ninkov ${ }^{1} \mathbb{D}$, Stanko Milić $^{1} \mathbb{D}$, Jovica Vasin ${ }^{1}$, Milorad Živanov ${ }^{1}$, Veljko Perović $^{2} \mathbb{D}$, \\ Borislav Banjac ${ }^{3}$, Savo Vučković ${ }^{4}$, Gordana Dozet ${ }^{5}$ and Vedrana Komlen ${ }^{6}$
}

1 Laboratory for Soil and Agroecology, Institute of Filed and Vegetable Crops, 21000 Novi Sad, Serbia; jordana.ninkov@ifvens.ns.ac.rs (J.N.); stanko.milic@ifvens.ns.ac.rs (S.M.); jovica.vasin@ifvcns.ns.ac.rs (J.V.); milorad.zivanov@ifvens.ns.ac.rs (M.Ž.)

2 Department of Ecology, Institute for Biological Research "Siniša Stanković", University of Belgrade, Bulevar Despota Stefana 142, 11060 Belgrade, Serbia; veljko.perovic@ibiss.bg.ac.rs

3 Faculty of Agriculture, University of Novi Sad, Trg Dositeja Obradovića 8, 21102 Novi Sad, Serbia; borislav.banjac@polj.edu.rs

4 Faculty of Agriculture, University of Belgrade, Nemanjina 6, 11080 Zemun, Serbia; savovuck@agrif.bg.ac.rs

5 Faculty of Biofarming, Megatrend University, Maršala Tita 39, 24300 Bačka Topola, Serbia; gdozet@biofarming.edu.rs

6 Agromediterranean Faculty, Džemal Bijedic University of Mostar, 88104 Mostar, Bosnia and Herzegovina; vedrana.komlen@unmo.ba

* Correspondence: snezana.p.jaksic@gmail.com; Tel.: +381-21-4898-463

\section{check for} updates

Citation: Jakšić, S.; Ninkov, J.; Milić, S.; Vasin, J.; Živanov, M.; Perović, V.; Banjac, B.; Vučković, S.; Dozet, G.; Komlen, V. Topographic Position, Land Use and Soil Management Effects on Soil Organic Carbon (Vineyard Region of Niš, Serbia). Agronomy 2021, 11, 1438. https:// doi.org/10.3390/agronomy11071438

Academic Editor: Adamo

Domenico Rombolà

Received: 2 June 2021

Accepted: 15 July 2021

Published: 20 July 2021

Publisher's Note: MDPI stays neutral with regard to jurisdictional claims in published maps and institutional affiliations.

Copyright: (c) 2021 by the authors. Licensee MDPI, Basel, Switzerland. This article is an open access article distributed under the terms and conditions of the Creative Commons Attribution (CC BY) license (https:// creativecommons.org/licenses/by/ $4.0 /)$.
Abstract: Spatial distribution of soil organic carbon (SOC) is the result of a combination of various factors related to both the natural environment and anthropogenic activities. The aim of this study was to examine (i) the state of SOC in topsoil and subsoil of vineyards compared to the nearest forest, (ii) the influence of soil management on SOC, (iii) the variation in SOC content with topographic position, (iv) the intensity of soil erosion in order to estimate the leaching of SOC from upper to lower topographic positions, and (v) the significance of SOC for the reduction of soil's susceptibility to compaction. The study area was the vineyard region of Niš, which represents a medium-sized vineyard region in Serbia. About 32\% of the total land area is affected, to some degree, by soil erosion. However, according to the mean annual soil loss rate, the total area is classified as having tolerable erosion risk. Land use was shown to be an important factor that controls SOC content. The vineyards contained less SOC than forest land. The SOC content was affected by topographic position. The interactive effect of topographic position and land use on SOC was significant. The SOC of forest land was significantly higher at the upper position than at the middle and lower positions. Spatial distribution of organic carbon in vineyards was not influenced by altitude, but occurred as a consequence of different soil management practices. The deep tillage at $60-80 \mathrm{~cm}$, along with application of organic amendments, showed the potential to preserve SOC in the subsoil and prevent carbon loss from the surface layer. Penetrometric resistance values indicated optimum soil compaction in the surface layer of the soil, while low permeability was observed in deeper layers. Increases in SOC content reduce soil compaction and thus the risk of erosion and landslides. Knowledge of soil carbon distribution as a function of topographic position, land use and soil management is important for sustainable production and climate change mitigation.

Keywords: soil organic carbon; viticulture; topography; land use; management

\section{Introduction}

Soil organic carbon (SOC) is key constituent of soil organic matter (SOM), which is an essential component of soils as it supports soil structure, fertility and a range of physical and chemical properties. Soil organic carbon stocks comprise the largest carbon pool in terrestrial ecosystems and act as a major source or sink for atmospheric $\mathrm{CO}_{2}[1,2]$. SOC sequestration is regarded as an option to mitigate climate change and is based on positive 
SOC budgets for specific land use and management systems, whereby the input of $\mathrm{C}$ into soils exceeds the losses of SOC through erosion, mineralization/volatilization and leaching [3]. Small changes in the SOC stock impact the carbon cycle and may significantly increase or decrease the carbon concentrations in the atmosphere [4]. Batjes [5] estimated the global SOC stock up to a $2 \mathrm{~m}$ depth to be $2060 \pm 215 \mathrm{Pg}$. C. Scharlemann et al. [6] reviewed the SOC estimations published in 27 studies from 1951 to 2014 and pointed out that there was a very considerable range of variation, between 504 and $3000 \mathrm{Pg}$. Responding to the current capacities for soil carbon sequestration, the initiative " 4 per Thousand" (4 p1000) was formed in Paris in 2015, with the aim of increasing awareness about land use responsibility and climate change [7].

Spatial distribution of SOC is the result of a combination of various factors related to both the natural environment and human activities, with heterogeneity observed at different spatial scales [8].

Land use is one of the main factors that control the distribution of SOC [9]. Changes in land use are the second most important source of greenhouse gas (GHG) emissions into the atmosphere after fossil fuel burning $[10,11]$. The replacement of forest and natural grassland by cropland may cause a reduction of SOC [12]. SOC loss after deforestation is between $30 \%$ and $42 \%$ and conversion from grassland to cropland caused a decline of $24-59 \%$ of total SOC $[13,14]$. Deng et al. [15] stated that cropland has lower SOC content compared to undisturbed natural soil due to the continual harvest of aboveground biomass. In contrast, improved soil management, like conversion from cropland into grassland and afforested land, can reduce emissions through SOC sequestration, since plant residues and roots are accumulated in the soil as soil organic matter [13].

Soil management can change the content and distribution of SOC. Tillage operations strongly control the soil environment. These effects influence many physical, chemical and biological properties of soil [16]. Conventional tillage has been shown to enhance short-term $\mathrm{CO}_{2}$ evolution and microbial biomass turnover, as well as accelerate organic $\mathrm{C}$ oxidation to $\mathrm{CO}_{2}$, not only by improving soil aeration but also by increasing contact between soil and crop residues and by exposing aggregate-protected organic matter to microbial attack [17].

Topographic position influences accumulation of SOC mainly by altering the input and output of carbon via hydrological processes $[18,19]$, and it affects soil erosion and sediment deposition [20], temperature regime, vegetation distribution, and soil processes [14]. Surface SOC concentration has been found to correlate negatively with annual mean temperature and correlate positively with annual mean precipitation and altitude [21]. However, in soils located on steeper terrain, organic matter accumulation often occurs at the bottom of the slope. There are two reasons for this accumulation: conditions are wetter, and organic matter is transported to the lowest point in the landscape through runoff and erosion [22]. Increases in SOM content at mid- or upper-slope positions may decrease soil erodibility and reduce risks of soil erosion [23].

Soil loss caused by erosion, with various categories of degradation, is a serious problem in the Republic of Serbia [24]. In the Niš region, which mainly belongs to the hilly, mountainous area of the country, a part of the surface is under the influence of high and severe intensity erosion, which requires the application of protective measures. Some of the measures include no-till farming, reduced tillage, terrace construction and maintenance, cover crops, continuous plant cover and crop rotation and shelterbelts. Also, in recent years, the trend for soil use changes has been very pronounced, especially the replacement of perennial crops with annual ones, which brings an additional risk of soil erosion and loss of organic matter. However, perennial plants are also endangered by these processes. In vineyards, erosion processes can be very pronounced because vineyards are usually based on steep and hilly terrain, as well as on mountains with southern exposure due to the better quality of grapes obtained [25,26]. Besides, due to specific soil properties in vineyards, such as limited soil development, coarse texture and low capacity to protect SOM binding 
to soil minerals, these soils are sensitive to degradation [27-29] and lose potentially more SOC than other agricultural soils.

To ensure sustainable land management and to protect the land from degradation, it is necessary to achieve a satisfactory level of SOC and maintain it. Thus, understanding soil carbon distribution as a function of topographic position, land use, soil management and their interaction is important for designing sustainable production and climate change mitigation that also contribute to food security [30,31]. These effects have not been studied enough in the soils of Serbia, especially not with regard to multiannual plantations like vineyards. This study represents a continuation of soil examination in vineyards. Previous research covered the vineyard region of Tri Morava in Serbia, examining the state of SOC and the impact of soil type and fertilization strategy on the organic carbon content of the soil [32].

The aim of this study was to examine (i) the state of SOC in topsoil and subsoil of vineyards compared to the nearest forest, (ii) the influence of soil management on SOC, (iii) the variation of SOC content with topographic position, (iv) soil erosion intensity in order to estimate the significance of SOC leaching from upper to lower topographic positions, (v) the significance of SOC for reducing the susceptibility of soil to compaction.

\section{Materials and Methods}

\subsection{Study Area}

The study area was the vineyard region of Niš (Figure 1), which represents a mediumsized vineyard region in Serbia with a surface area of $1040.84 \mathrm{~km}^{2}$. This region is located between $43^{\circ} 41^{\prime} \mathrm{N}$ and $43^{\circ} 13^{\prime} \mathrm{N}$.

The Niš region includes vineyards located in the valley of the lower Nisava river basin and the lower basins of the Južna Morava and Moravica rivers. Although in previous periods the areas used for vineyards in the Niš region were much larger, currently there are $13.12 \mathrm{~km}^{2}$ of vineyards [33].

There are six vine growing districts in this region (Figure 1a): Sokobanja, Aleksinac, Žitkovac, Čegar, Kutina and Svrljig [34]. The relief characteristics of the region are visible at three general altitudes (Figure 1b): (1) plains around the rivers in the southeast/northwest directions-lower level; (2) areas with hills and ridges on both sides of the valleys (except in the southwestern part of the region)-higher level; and (3) the ends of the mentioned mountains in the northeast and a small part in the west (near the mountain Jastrebac)-the highest mountain level. Most of the plots (48.11\%) are located at altitudes between 200 and $300 \mathrm{~m} ; 28.11 \%$ are located at altitudes of 300 to $400 \mathrm{~m}$, while $13.02 \%$ are located at altitudes of 400 to $500 \mathrm{~m}$. At other altitudes, there are significantly lower shares of the plots.

Viticultural plots in the Niš region are mostly located on flat and slightly steep terrains: $43.39 \%$ of the plots are located on terrain with a slope greater than 0 to $5^{\circ}$ (Figure $1 \mathrm{c}$ ). The share of vineyard plots in the Niš region on slopes greater than 5 to $10^{\circ}$ is $26.42 \%$, while $16.04 \%$ of plots are located on very steep terrain (slopes greater than 10 to $15^{\circ}$ ) [34].

Figure $1 \mathrm{~d}$ shows that the plots in the Niš region are mostly located in the south (S) $(31.5 \%)$, southwest (SW) $(19.16 \%)$ and southeast (SE) $(14.04 \%)$ and in western (W) $(11.95 \%)$ and eastern (I) exposures (7.40\%) [34].

Significant pedological diversity, i.e., the diversity of soil types, is expressed in the Niš viticultural region (Figure 2). The Niš wine-growing region consists of fourteen different types of soil represented by larger or smaller areas, and the most common soil types are vertisol, eutric cambisol and luvisol. 


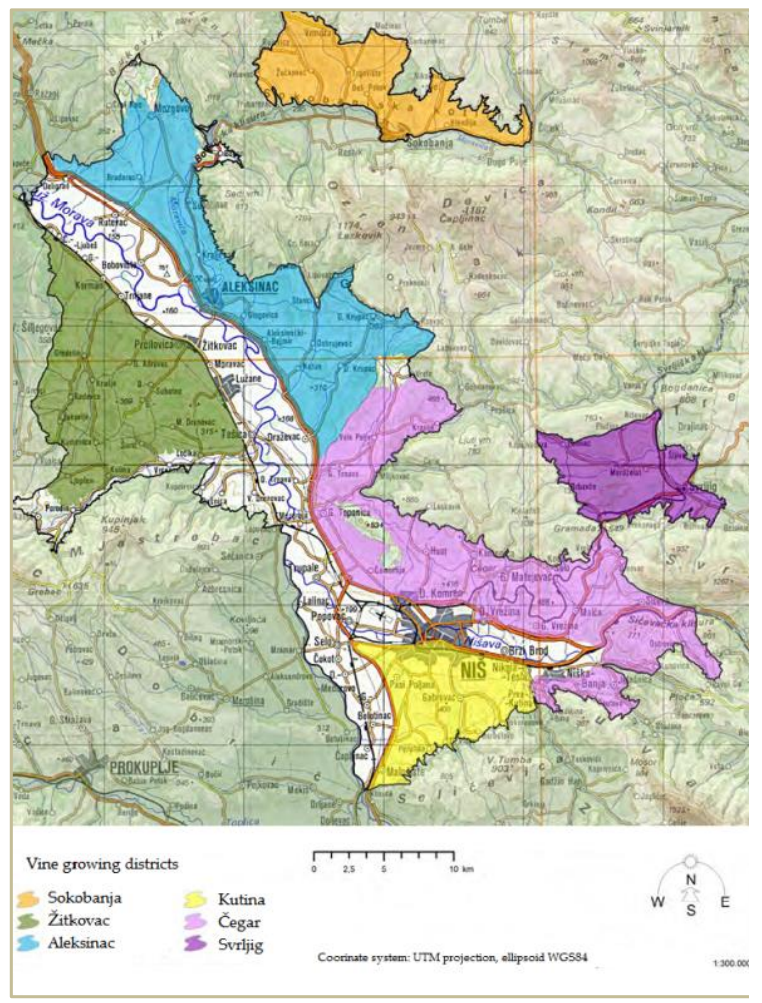

(a)

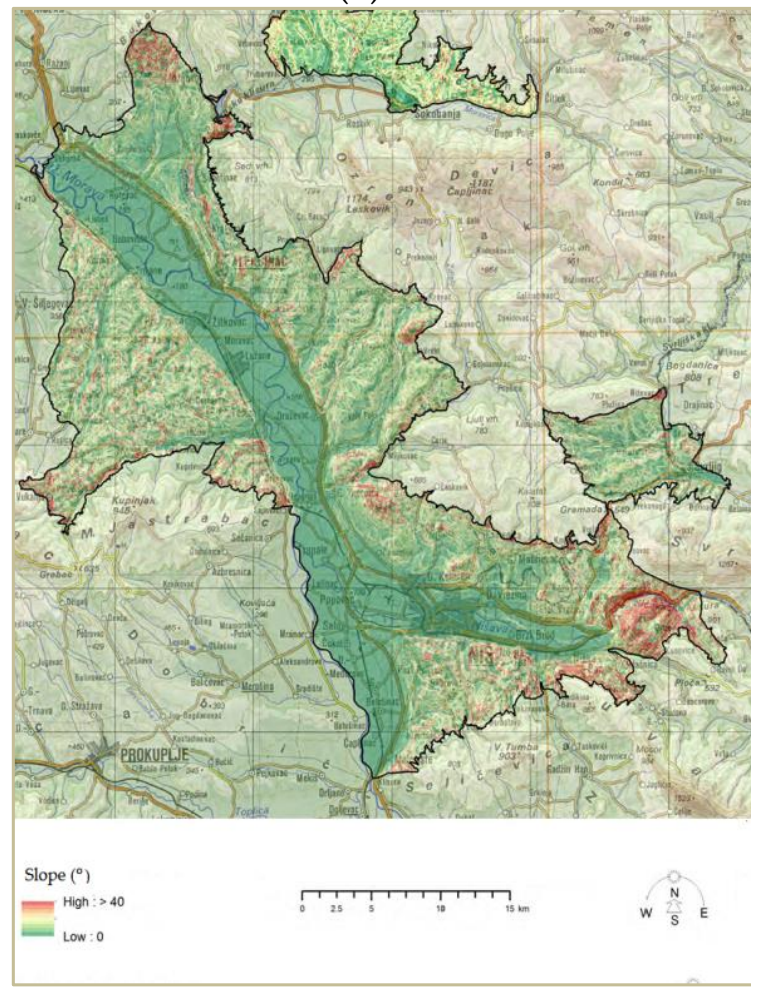

(c)

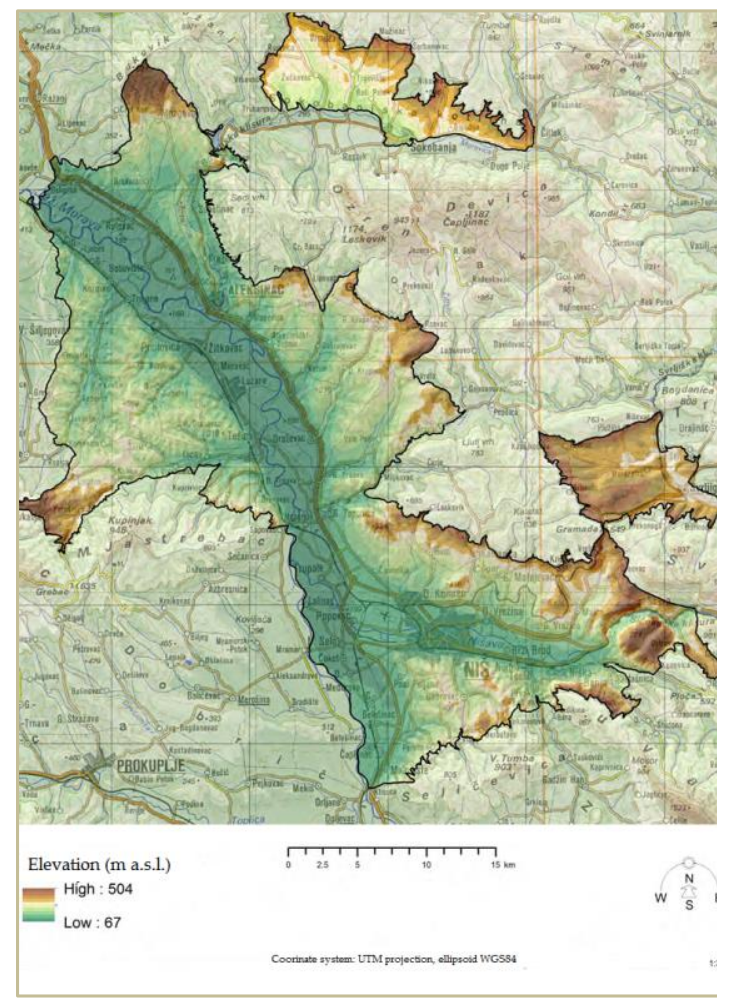

(b)

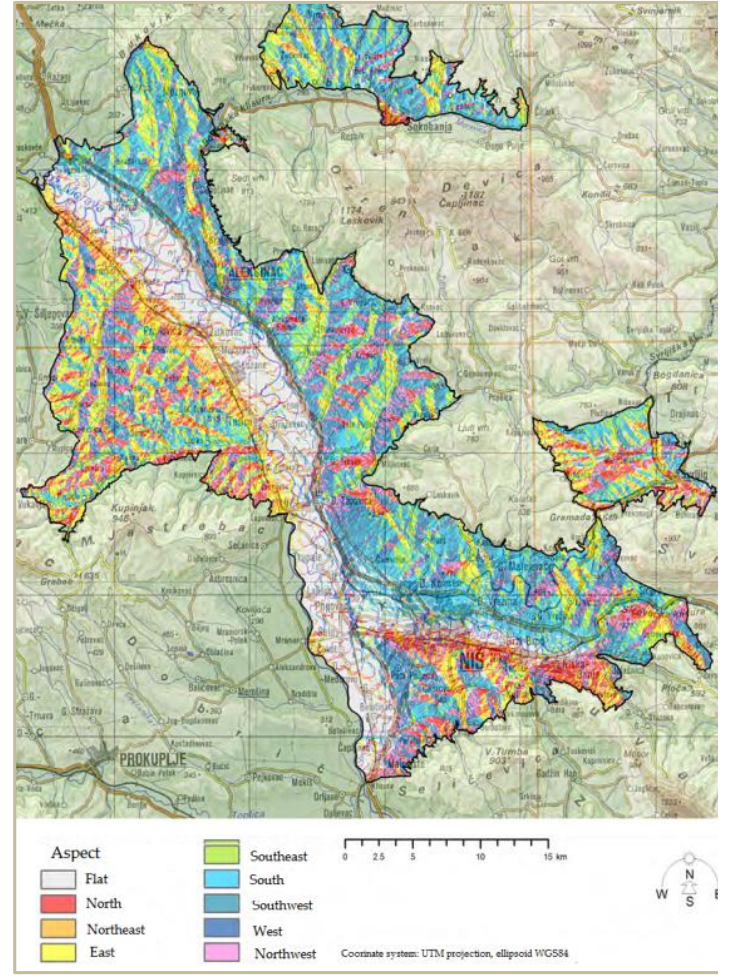

(d)

Figure 1. The vineyard region of Niš, Serbia: (a) vine-growing districts; (b) elevation (m.a.s.l.); (c) slope $\left(^{\circ}\right)$; (d) aspect ([33], modified by the authors). 


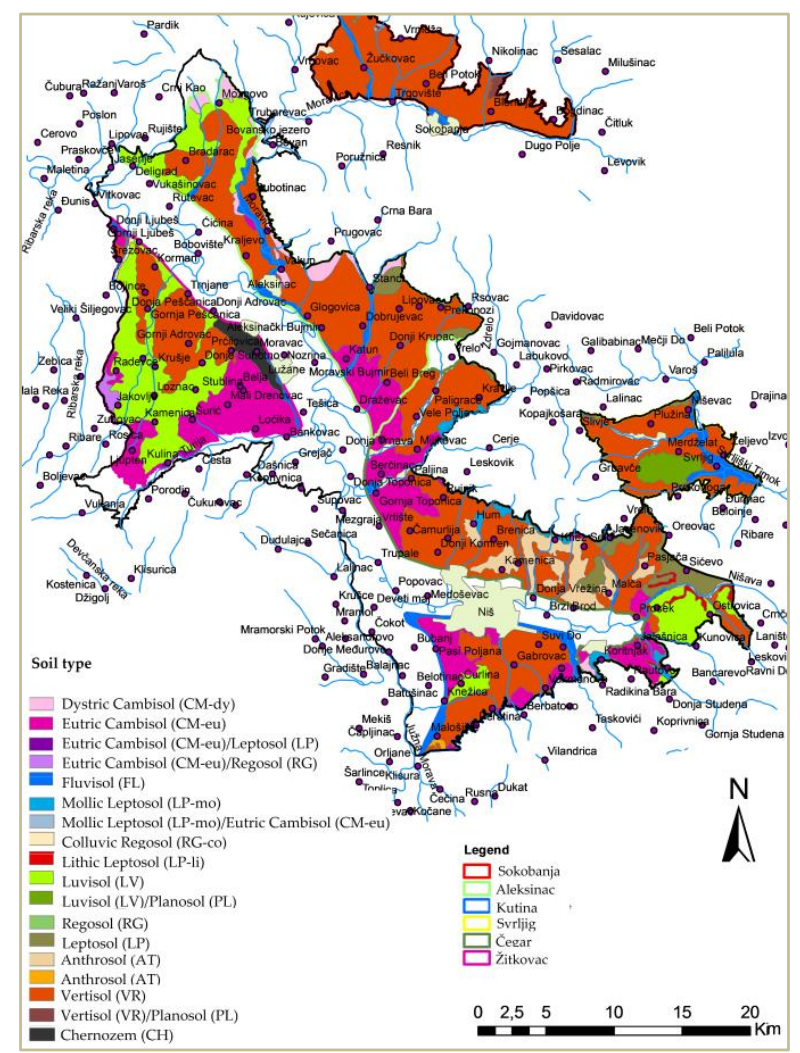

Figure 2. Pedological map of the wine-growing region of Niš and borders of vine-growing districts, according to the World Reference Base (WRB) soil classification; based on a digitalized primary pedological map of the Republic of Serbia, 1:50,000.

\subsection{Climate Characteristics}

Climatological data were obtained from four meteorological stations: Niš (Jasenovik, Malča, Sićevo and Gornji Barbeš localities), Aleksinac (Jasenje, Šurić, Beli Breg and Vele Polje localities), Sokobanja (Beli Potok locality) and RC Niš (Svrljig locality).

For the last 20 years, the mean annual air temperatures were $12.4,9.3,13$ and $11.2{ }^{\circ} \mathrm{C}$ at the Niš (204 m.a.s.l.), RC Niš (807 m.a.s.l.), Aleksinac (180 m.a.s.l.) and Sokobanja (300 m.a.s.l.) meteorological stations, respectively (Figure 3). The heat summation period (April-October), also known as the Winkler index, is 1713.8, placing this region in zone III according to Winkler [34].

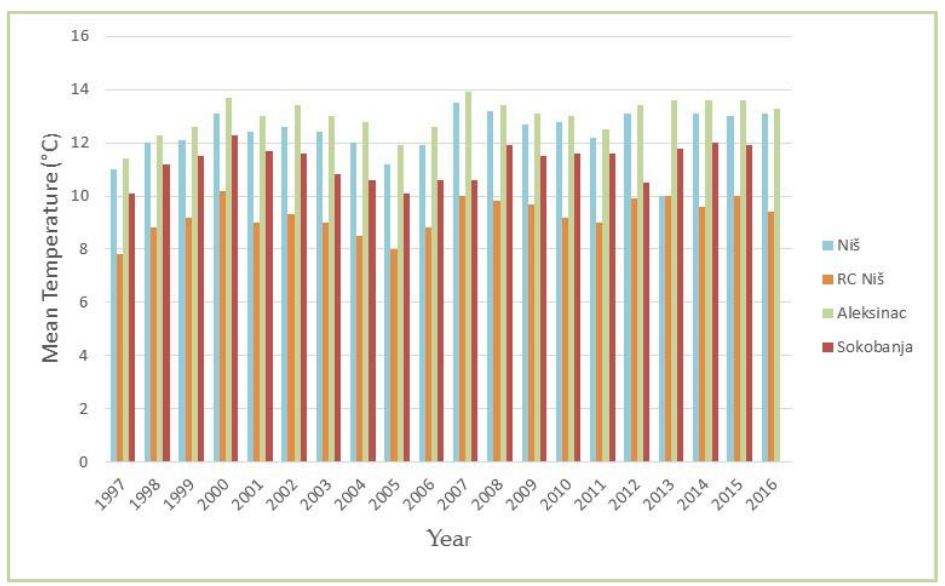

Figure 3. Mean annual temperatures in the Niš region from 1997 to 2016, obtained from four meteorological stations. 
Huglin's (heliothermic) index (HI) (April-September) for the Niš region is 2259.7, which puts the lower parts of the region in the $\mathrm{HI}+1$ group of regions, in the interval > $2100 \leq 2400$ with the climate type moderate-warm [35]. The value of the drought index for the Niš region is $138.0 \mathrm{~mm}$, which classifies this region as a DI-1 sub-humid (medium humid) region, with typical absence of drought [36].

For the last 20 years, the mean annual precipitation levels were 629, 746, 624 and $700 \mathrm{~mm}$ at the Niš, RC Niš, Aleksinac and Sokobanja meteorological stations, respectively (Figure 4).

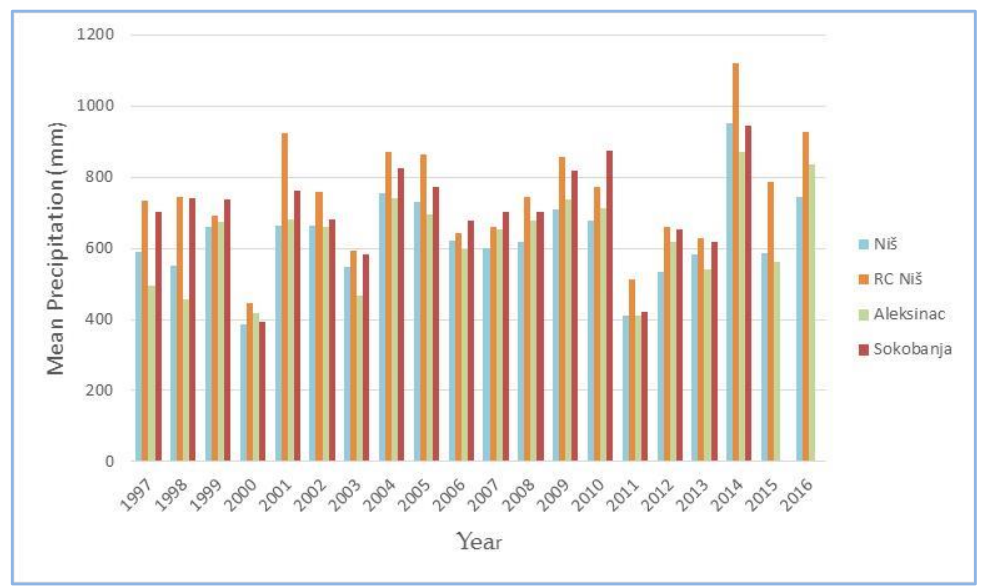

Figure 4. Mean annual precipitation levels in the Niš region from 1997 to 2016, obtained from four meteorological stations.

\subsection{Soil Management Practices}

The soil management data were derived from long-term management records for the period 1997-2016. Soil management practices usually involve ameliorative fertilization with large amounts of mineral fertilizers (300-500 $\mathrm{kg} \mathrm{P}_{2} \mathrm{O}_{5} \mathrm{ha}^{-1}$ and 200-300 $\mathrm{kg} \mathrm{K}_{2} \mathrm{O} \mathrm{ha}^{-1}$ ) with the addition of organic amendments, most often manure (30-40 tha $\left.{ }^{-1}\right)$, when planting vineyards. Common practice also includes deep tillage to an average depth of $60-80 \mathrm{~cm}$, mixing of soil horizons and placing of organic materials into deeper soil layers. Some wine producers avoid deep tillage and plow at $30-40 \mathrm{~cm}$. In the first years of the vineyard plantation, no fertilization is carried out, or smaller amounts of mineral fertilizer are applied. During the following years of exploitation, mineral fertilizers are applied, while opinions are divided on the issue of applying organic fertilizers. Some wine producers avoid using organic fertilizers for grape production, because they fear there will be a negative impact on the quality of the grapes. Winegrowers generally do not bring grape pomace back to the soils. Other growers apply organic fertilizers, usually manure, every fourth year. Frequent tillage between the rows is a common practice during exploitation to keep the soil free of weeds.

\subsection{Soil Sampling}

The study was carried out in 10 representative vineyard localities (Table 1). Some localities are shown in Figure 5 and Supplementary Materials, Figure S1. Field work took place during 2016. In each topographic position samples were taken from the vineyard and forest soils. The total analyzed area included 20 production vineyard plots and 10 forest soils in the close vicinity of the vineyard plots. These plots exhibited uniform micro-relief and slope in their terrain, as well as having the same cultivation practices. The size of the plots (subplots) varied from 1400 to $34,500 \mathrm{~m}^{2}$. 
Table 1. Locations, vine growing districts, global positioning system (GPS) coordinates and soil types of the vineyards.

\begin{tabular}{ccccc}
\hline Locality & Vine Growing District & GPS (E) & GPS (N) & Soil Type (FAO-WRB) \\
\hline Jasenje & Aleksinac & 21.575951 & 43.629562 & Haplic vertisol (ochric), VR-ha-oh \\
Šurić & Žitkovac & 21.644822 & 43.453924 & Haplic vertisol (ochric), VR-ha-oh \\
Beli Breg & Aleksinac & 21.814915 & 43.478903 & Haplic vertisol (ochric), VR-ha-oh \\
Beli Potok & Sokobanja & 21.859135 & 43.674641 & Haplic vertisol (ochric), VR-ha-oh \\
Vele Polje & Čegar & 21.827743 & 43.450464 & Haplic vertisol (ochric), VR-ha-oh \\
Svrljig & Svrljig & 22.069715 & 43.414675 & Abruptic luvisol (clayic), LV-ap-ce \\
Jasenovik & Čegar & 22.030862 & 43.355521 & Haplic vertisol (ochric), VR-ha-oh \\
Malča & Čegar & 22.010568 & 43.316971 & Haplic vertisol, VR-ha-oh \\
Sićevo & Čegar & 22.081987 & 43.346480 & Skeletic, dolomitic, eutric leptosol (clayic, ochric), \\
Gornji Barbeř & Kutina & 21.950723 & 43.188976 & LP-sk.do.eu-ce.oh \\
\hline
\end{tabular}

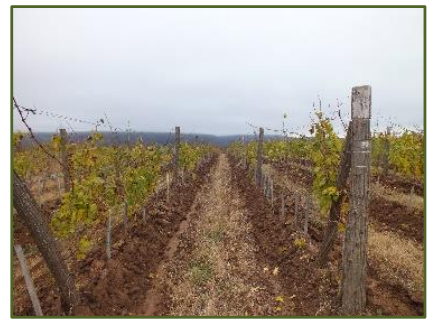

(a)

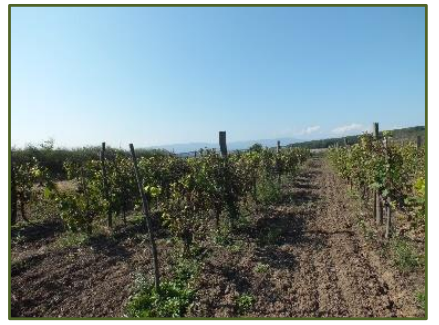

(b)

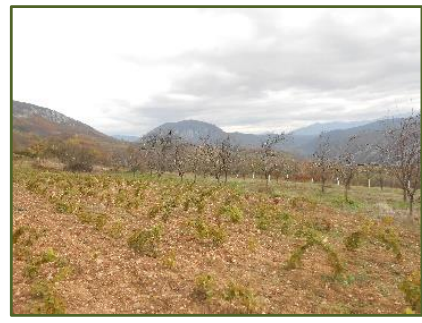

(c)

Figure 5. Some localities of the vine-growing region of Niš: (a) Svrljig-abruptic luvisol (clayic), LV-ap-ce; (b) Beli Breg-haplic vertisol (ochric), VR-ha-oh; (c) Sićevo—skeletic, dolomitic, eutric leptosol (clayic, ochric), LP-sk.do.eu-ce.oh.

The soil was sampled from two depths, $0-30 \mathrm{~cm}$ and $30-60 \mathrm{~cm}$. Composite soil samples amounted to about 20 individual samples. The total number of these composite soil samples was 60 .

In order to determine the indigenous soil type of the vineyard, i.e., the soil that had not been altered by powerful ameliorative measures (deep tillage) during the vineyard establishment and turned into an anthrosol (eutric, clayic, regic; AT-eu.ce.rg), soil profiles were analyzed at a nondisturbed site in the vineyards or near the vineyards (Figure 6).

Soil profiles were analyzed at 10 representative locations, up to a maximum depth of $200 \mathrm{~cm}$ or to the parent material. Samples for soil profile description and classification were taken in disturbed state using an Eijkelkamp Edelman auger. The total number of this soil samples was 45 .

Georeferencing of soil and parcel samples in this study was performed using GPS receivers (Trimble GPS GeoXH 3000, Trimble GPS Juno SC, Terrasync Professional software; Trimble, Inc., Sunnyvale, CA, USA). Data processing was carried out using the ESRI ArcEditor 10 geographic information system (GIS).

\subsection{Soil Compaction Measurement}

Soil compaction was determined using an Eijkelkamp penetrologger by measuring resistance to penetration in all plots. The measurement depth was $80 \mathrm{~cm}$. The threshold values of soil compaction are shown in Table 2.

Table 2. Threshold values of soil compaction [37].

\begin{tabular}{cc}
\hline Soil Compaction & Threshold Values \\
\hline Optimal & $1.0-2.5 \mathrm{MPa}$ \\
Moderate compaction & $2.5-3.0 \mathrm{MPa}$ \\
High compaction & $3.0-5.0 \mathrm{MPa}$ \\
\hline
\end{tabular}




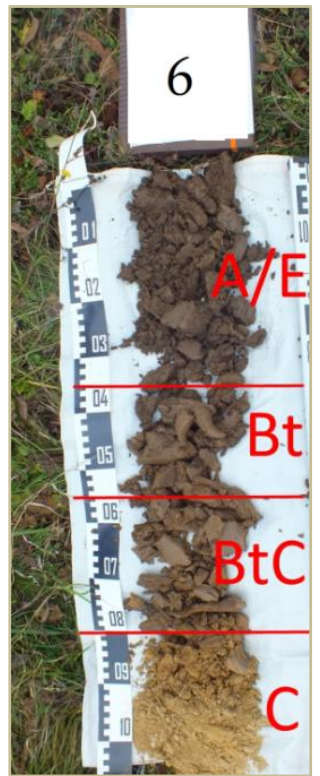

(a)

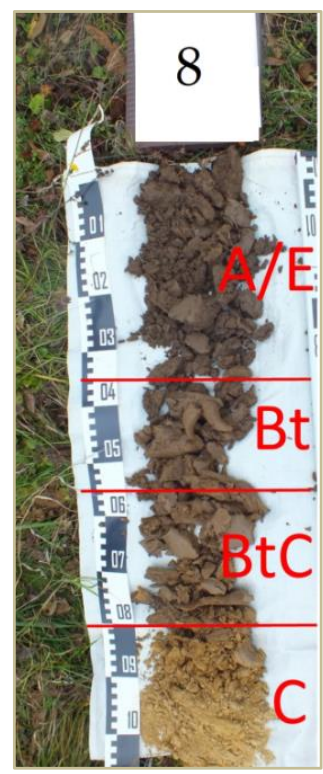

(b)

Figure 6. Some of the soil profiles: (a) Svrljig locality—abruptic luvisol (clayic), LV-ap-ce; (b) Malča locality-haplic vertisol, VR-ha-oh.

\subsection{Laboratory Analysis}

All laboratory analyses were performed at the Laboratory for Soil and Agroecology of the Institute of Field and Vegetable Crops, accredited according to the standard ISO/IEC 17025:2017 [38].

The soil samples collected were naturally air-dried, milled and passed through a $2.0 \mathrm{~mm}$ sieve, following ISO 11464:2006 [39]. Soil pH value was determined with the potentiometric method following ISO 10390:2005 [40] in a 1:5 suspension of soil in $1 \mathrm{M} \mathrm{KCl}$ using a Mettler Toledo SevenCompact $\mathrm{pH}$ meter with glass electrode (Mettler Toledo, LLC, Columbus, $\mathrm{OH}, \mathrm{USA})$. The carbonate content $\left(\mathrm{as}_{\mathrm{CaCO}}\right)$ was determined according to the ISO 10693:1995 [41] volumetric method. SOC was determined by elementary analysis using a CHNSO VarioEL III Elementar (Elementar Analysensysteme GmbH, Langenselbold, Germany) after dry combustion and carbonate removal, in accordance with ISO 10694:1995 [42]. The particle size distribution was determined in the $<2 \mathrm{~mm}$ fraction using the pipette method [43]. The size fractions were defined as clay $(<2 \mu \mathrm{m})$, silt $(2-20 \mu \mathrm{m})$, fine sand $(20-200 \mu \mathrm{m})$ and coarse sand $(200-2000 \mu \mathrm{m})$.

\subsection{Soil Erosion Intensity Assessment}

Soil erosion intensity assessment was carried out using the Universal Soil Loss Equation (USLE) model [44]:

$$
\mathrm{A}=\mathrm{R} \cdot \mathrm{K} \cdot \mathrm{LS} \cdot \mathrm{C} \cdot \mathrm{P}
$$

where $\mathrm{A}\left(\mathrm{t} \mathrm{ha} \mathrm{Cr}^{-1} \mathrm{yr}^{-1}\right)$ is the mean annual soil loss, $\mathrm{R}\left(\mathrm{MJ} \mathrm{mm} \mathrm{h} \mathrm{h}^{-1} \mathrm{ha}^{-1} \mathrm{y}^{-1}\right)$ is the rainfall erosivity factor, $\mathrm{K}\left(\mathrm{t}\right.$ ha h ha ${ }^{-1} \mathrm{MJ}^{-1} \mathrm{~mm}^{-1}$ ) is the soil erodibility factor, $\mathrm{LS}$ is the topographic factor, $\mathrm{C}$ is the land use/cover factor, and $\mathrm{P}$ is the practice factor (conversational measures, because erosion measures in the examined area were not taken into account).

Climatic data from the measuring stations around the studied territory were used to calculate the R factor. In this study, a simplified GJRM model was used to obtain the value of this factor $[45,46]$. The $\mathrm{K}$ factor was calculated using the Wischmeier and Smith equations [44]. In generating the LS factor of the study area, the SAGA GIS module was used, calculated from the ratio developed by Desmet and Govers [47], while the CLC database was used to calculate the $C$ factor. 
The classification of soil erosion risk categories according to the Organization for Economic Cooperation and Development (OECD) [48] uses the following ranges: tolerable (<6.0 $\mathrm{t} \mathrm{ha}^{-1} \mathrm{yr}^{-1}$ ), low (6.1-10.0 $\left.\mathrm{t} \mathrm{ha}^{-1} \mathrm{yr}^{-1}\right)$, moderate (10.1-22.0 $\left.\mathrm{t} \mathrm{ha}^{-1} \mathrm{yr}^{-1}\right)$, high (22.1-33.0 $\mathrm{tha}^{-1} \mathrm{yr}^{-1}$ ) and severe erosion (>33.1 $\left.\mathrm{tha}^{-1} \mathrm{yr}^{-1}\right)$.

\subsection{Statistical Analyses}

Study data were processed using the methods of descriptive statistics. A general linear mixed model was fitted for SOC data. All factors, including the main effects of land use, topographic position and soil depth, as well as the corresponding interactions in the model, were considered as fixed. Additionally to this base model, several alternative candidate models with diagonal structures for the main effects and interactions were fitted. The best model based on the AIC value criterion was selected for further discussion and for least squares means comparisons. The differences were tested when significant effects were detected. Correlation analysis between SOC content and resistance to penetration of soil, as well as between mean annual soil loss and altitude, was explored by using the Pearson correlation at a significance level of $p<0.05$. All statistical analyses were performed using SAS software and Statistica 12.6 (StatSoft, Inc. Corporation, Tulsa, OK, USA).

\section{Results and Discussion}

\subsection{Characteristics of the Soil}

Physical and chemical soil properties of the investigated area for the soil layers at 0-30 $\mathrm{cm}$ and $30-60 \mathrm{~cm}$ and for the profile horizons $(<200 \mathrm{~cm})$ are given in Table 3 . In topsoil and subsoil, the $\mathrm{pH}$ value was highly acid to slightly alkaline, according to the classification for vineyard soils [49]. Soil $\mathrm{pH}$ value comes from the $\mathrm{pH}$ reaction of the parent substrate in which the soil was formed. The topsoil layer $(0-30 \mathrm{~cm})$ had an acidic $\mathrm{pH}$ value for the most part (62\% of the region's surface area). In the soil profile horizons, the $\mathrm{pH}$ values of most soils increased with depth. The most suitable soil $\mathrm{pH}$ in terms of vine cultivation is neutral [50]. According to White [51], the optimum $\mathrm{pH}$ range for vine growth is 5.5-8. Slightly acidic and neutral vineyard soils have a better nutrient balance for plant growth.

Table 3. Descriptive statistics of soil properties in layers: $0-30 \mathrm{~cm}, 30-60 \mathrm{~cm}$ and profile horizons $(<200 \mathrm{~cm})$.

\begin{tabular}{cc}
\hline Soil Properties & Mean \pm Standard Deviation \\
\hline & $0-30 \mathrm{~cm}$ \\
\hline $\mathrm{pH}$ (in 1 M KCl) & $5.42 \pm 1.15$ \\
$\mathrm{CaCO}_{3}(\%)$ & $2.65 \pm 10.84$ \\
$\mathrm{Clay}(\%)^{\text {Silt }(\%)}$ & $36.67 \pm 9.91$ \\
Fine sand (\%) & $22.32 \pm 4.86$ \\
Coarse sand (\%) & $28.57 \pm 7.17$ \\
& $12.44 \pm 8.26$ \\
\hline $\mathrm{pH}$ (in 1 M KCl) & \\
CaCO $(\%)$ & $5.46 \pm 1.15$ \\
Clay (\%) & $5.01 \pm 10.84$ \\
Silt (\%) & $39.92 \pm 9.78$ \\
Fine sand (\%) & $21.35 \pm 4.94$ \\
Coarse sand (\%) & $26.71 \pm 7.28$ \\
& $12.02 \pm 8.24$ \\
\hline pH (in 1 M KCl) & \\
CaCO $(\%)$ & $5.62 \pm 1.13$ \\
Clay (\%) & $6.26 \pm 10.79$ \\
Silt (\%) & $35.12 \pm 9.93$ \\
Fine sand (\%) & $21.04 \pm 4.85$ \\
Coarse sand (\%) & $31.04 \pm 7.18$ \\
\hline
\end{tabular}


Samples of topsoil and subsoil belonged to the noncalcareous to highly calcareous soil categories [49]. The content of $\mathrm{CaCO}_{3}$ in completely carbonate-free soils was either uniform in terms of profile depth or a small amount of carbonates appeared at the lower layer. In other soils, the carbonate content increased with the depth of the profile. The content of $\mathrm{CaCO}_{3}$ largely depended on the parent substrate.

Increased clay content was recorded in both soil layers and varied between $21.44 \%$ and $61.88 \%$ in topsoil and $21.56 \%$ and $51.92 \%$ in subsoil. Most of the samples were concentrated in the classes of light clay and heavy clay. This texture is unfavorable for most cultivated plant species. Loamy soils with high organic matter, low-water-holding capacity and well-drained characteristics are more suitable for plant production [52].

\subsection{Intensity of Soil Erosion}

The mean annual soil loss in the Niš region was $5.42 \mathrm{t} \mathrm{ha}^{-1} \mathrm{yr}^{-1}$, determined using the USLE model [44] (Figure 7). The average erosion intensity in the observed localities ranged between 0.05 and $9.80 \mathrm{t} \mathrm{ha}^{-1} \mathrm{yr}^{-1}$, with a mean value of $4.43 \mathrm{tha}^{-1} \mathrm{yr}^{-1}$ (Table 4), which classifies this area as having tolerable erosion risk according to the OECD classification [48].

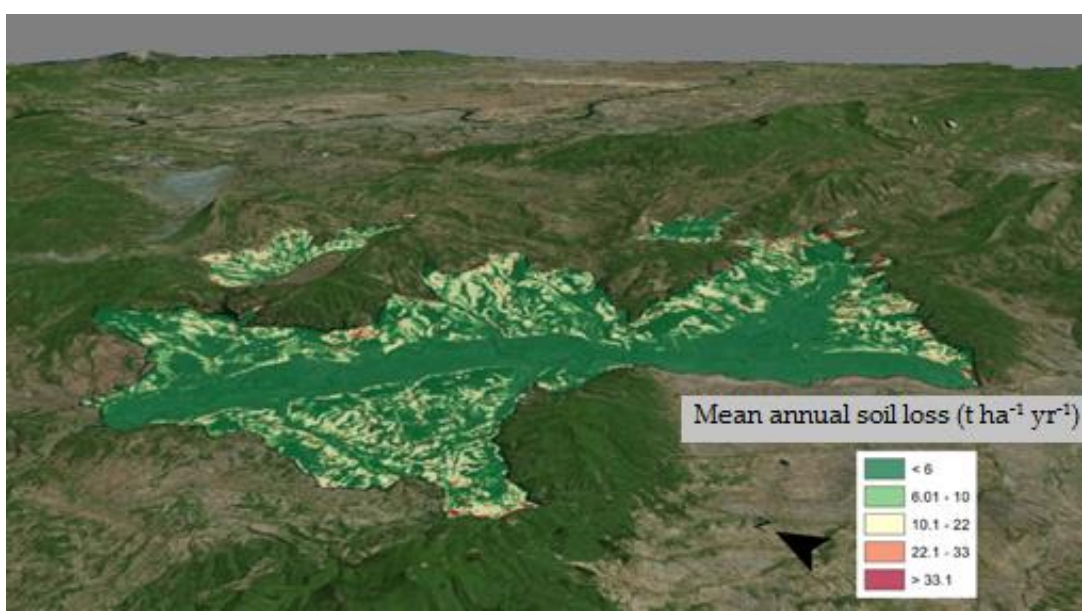

Figure 7. Mean annual soil loss in the Niš region $\left(t \mathrm{tha}^{-1} \mathrm{y}^{-1}\right)$.

Table 4. Mean annual soil loss in observed localities.

\begin{tabular}{cc}
\hline Locality & A \\
\hline Jasenje & 5.64 \\
Šurić & 5.83 \\
Beli Breg & 3.43 \\
Beli Potok & 9.82 \\
Vele Polje & 5.86 \\
Svrljig & 0.58 \\
Jasenovik & 1.78 \\
Malča & 2.77 \\
Sićevo & 8.81 \\
Gornji Barbeš & 3.24 \\
\hline
\end{tabular}

A-Mean annual soil loss $\left(\mathrm{t} \mathrm{ha}^{-1} \mathrm{yr}^{-1}\right)$.

A low risk of surface soil erosion was determined for $12.45 \%$ of the surface, while $16.52 \%$ of the territory was found to be under a moderate erosion processes. High risk of erosion was detected for $2.73 \%$ of the territory and severe risk of soil erosion was observed for $0.73 \%$ of the territory. The most endangered vine-growing districts were Sokobanja, with $8.15 \%$ of the territory under high and severe risk and Čegar, with $5.92 \%$ of the territory under high and severe risk. The highest mean annual soil loss was in the Beli Potok $\left(9.80 \mathrm{tha}^{-1} \mathrm{yr}^{-1}\right)$ and Sićevo $\left(8.81 \mathrm{tha}^{-1} \mathrm{yr}^{-1}\right)$ localities. The lowest mean annual soil loss was in the Svrljig locality $\left(0.58 \mathrm{t} \mathrm{ha}^{-1} \mathrm{yr}^{-1}\right)$. 


\subsection{Effect of Topographic Position and Soil Depth on SOC Content}

The effect of topographic position on SOC content is shown in Table 5 and Figure 8. After fitting several candidate models that assumed heterogeneous error variance for the model term, the most suitable model with a heterogeneous error variance structure for the factors was selected based on the AIC value (data not shown). All further discussion (throughout the study) is based on inferences from the selected model. Topographic position was a significant factor, while soil depth was highly significant.

Table 5. Tests of fixed effects from the model with a suitable error variance structure.

\begin{tabular}{ccccc}
\hline Effect & Num DF & Den DF & F-Value & Pr $>$ F \\
\hline Land use & 1 & 18.2 & 8.57 & 0.0089 \\
Soil depth & 1 & 18.2 & 12.33 & 0.0025 \\
Topographic position & 2 & 18.2 & 5.35 & 0.0148 \\
Land use $\times$ soil depth & 1 & 18.2 & 0.68 & 0.4191 \\
Land use $\times$ topographic position & 2 & 18.2 & 5.76 & 0.0115 \\
Soil depth $\times$ topographic position & 2 & 18.2 & 0.01 & 0.9910 \\
Land use $\times$ soil depth $\times$ topographic position & 2 & 18.2 & 0.08 & 0.9248 \\
\hline
\end{tabular}

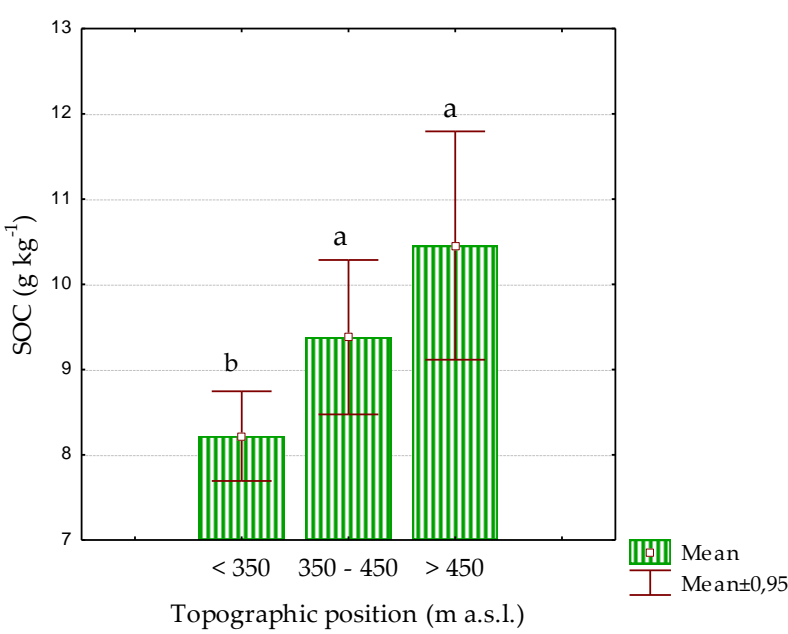

(a)

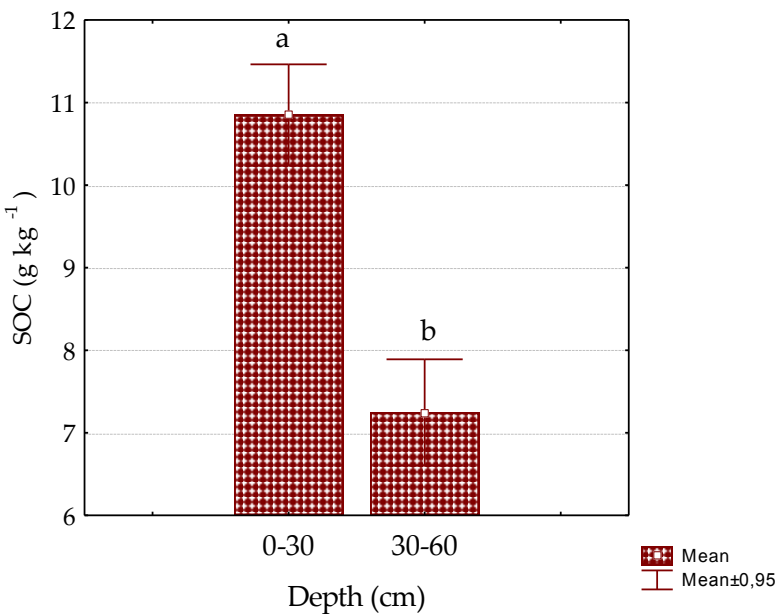

(b)

Figure 8. Soil organic carbon content: (a) for different topographic positions, $p<0.05$; (b) in soil layers, $p<0.01$ Significant differences between soil groups are labeled with different letters, $(\mathrm{N}=60)$.

The SOC content was significantly higher at the upper and the middle position than at the lower positions. The SOC in the lower topographic position ( $<350$ m.a.s.l.) of the vine-growing region of Niš ranged between 2.55 and $13.46 \mathrm{~g} \mathrm{~kg}^{-1}$, with a mean value of $8.22 \mathrm{~g} \mathrm{~kg}^{-1}$. At $350-450 \mathrm{~m}$, SOC content ranged from $3.48 \mathrm{~g} \mathrm{~kg}^{-1}$ to $14.09 \mathrm{~g} \mathrm{~kg}^{-1}$, with a mean value of $9.38 \mathrm{~g} \mathrm{~kg}^{-1}$. At the highest altitudes above $450 \mathrm{~m}$, the SOC content ranged from $5.34 \mathrm{~g} \mathrm{~kg}^{-1}$ to $24.13 \mathrm{~g} \mathrm{~kg}^{-1}$, with a mean value of $10.45 \mathrm{~g} \mathrm{~kg}^{-1}$.

These results might be attributable to the differences in temperature and precipitation between different topographic positions. Decreasing temperature and increasing precipitation with altitude can be seen in Figures 3 and 4. The highest mean annual precipitation $(746 \mathrm{~mm})$ and the lowest temperature $\left(9.3^{\circ} \mathrm{C}\right)$ were at the highest altitude $(807 \mathrm{~m}$.a.s.l.) The lowest mean annual precipitation $(624 \mathrm{~mm})$ and the highest temperature $\left(13^{\circ} \mathrm{C}\right)$ were at the lowest altitude (180 m.a.s.l.).

Altitude affects climatic characteristics, composition and productivity of vegetation [51], soil water balance, soil erosion, geological deposition processes, soil microbiological activity and other processes [52,53], thereby influencing the content of and changes in organic carbon in the soil. At higher altitudes, SOC accumulation is higher due to decreases in temperature and increasing levels of soil moisture [54-56]. At the, 
increasing soil temperature accelerates the rate of SOC decomposition $[57,58]$, improves the level of soil respiration [57] and leads to a significant decrease in SOC content [58-60]. These findings are consistent with the results obtained by Sims and Nielsen [61], who reported that SOC had a significant relationship with altitude in Montana, USA. Also, Dai and Huang [62] reported that SOC stocks had a linear and positive correlation with altitude. Decreasing temperature with altitude has been shown to limit SOC turnover in forest soils, leading to enhanced SOC storage [63]. lower positions

Previous studies in Serbian soils have shown that organic carbon content has decreased from $52.7 \mathrm{~g} \mathrm{~kg}^{-1}$ (1450 m.a.s.l.) to $39.4 \mathrm{~g} \mathrm{~kg}^{-1}$ (500 m.a.s.l.) [21]. In the study by Vidojević [55], SOC increased from lower to upper positions. In this study, the SOC content was: $35.60 \mathrm{~g} \mathrm{~kg}^{-1}$ at $500-1000$ m.a.s.l., $18.70 \mathrm{~g} \mathrm{~kg}^{-1}$ at $200-500$ m.a.s.l. and $15.20 \mathrm{~g} \mathrm{~kg}^{-1}$ at altitudes below 200 m.a.s.l. In the examination by Fang et al. [64], SOC in forest land increased with altitude and levels were significantly different at $0-200$ and $400-800 \mathrm{~m}$ in the $10-30 \mathrm{~cm}$ soil layer. Similar results were obtained by Abebe et al. [65], where SOC stock in bushland was the highest $\left(166.22 \mathrm{Mg} \mathrm{ha}^{-1}\right)$ in the upper position.

In contrast, numerous studies have confirmed carbon leaching through erosion related to topography [65-68]. With increasing slope, infiltration decreases because the increasing slope area and the velocity of the water flow lead to increasing runoff. Although a part of the surface of the examined area was endangered by erosion processes, a high threat of erosion was found only for $2.73 \%$ of the territory and a severe threat for $0.73 \%$. The average erosion intensity in the observed localities ranged between 0.05 and $9.80 \mathrm{tha}^{-1} \mathrm{yr}^{-1}$, with a mean value of $4.43 \mathrm{t} \mathrm{ha}^{-1} \mathrm{yr}^{-1}$, which classifies this area as having tolerable soil loss according to the OECD classification [48]. The correlation between mean annual soil loss and altitude $(r=0.29)$ was not significant. It can be concluded that erosion did not significantly contribute to leaching of organic matter.

The overall mean SOC concentration of the samples in topsoil $(0-30 \mathrm{~cm}), 10.85 \mathrm{~g} \mathrm{~kg}^{-1}$, was significantly higher than SOC concentrations in subsoil $(30-60 \mathrm{~cm}), 7.25 \mathrm{~g} \mathrm{~kg}^{-1}$. This is in agreement with the results of other research $[1,32]$.

\subsection{The SOC Content for Different Land Uses}

The SOC contents were significantly affected by land use (Table 5 and Figure 9). Vineyard areas exhibited lower values of SOC $\left(8.28 \mathrm{~g} \mathrm{~kg}^{-1}\right)$ compared to forest areas $\left(10.58 \mathrm{~g} \mathrm{~kg}^{-1}\right)$, indicating that the management adopted in these areas contributed to the reduction of these fractions. Forests have dense cover, which protects soil from being exposed to any other factors, such as erosion; hence, the SOC content is less affected [69]. This finding has been confirmed by many authors, who have shown that forest soils supply a large carbon input and have low litter decomposition [32]. This means that forest soils are distinguished by higher SOC, which is highly related to the lower degree of natural and human-induced disturbance.

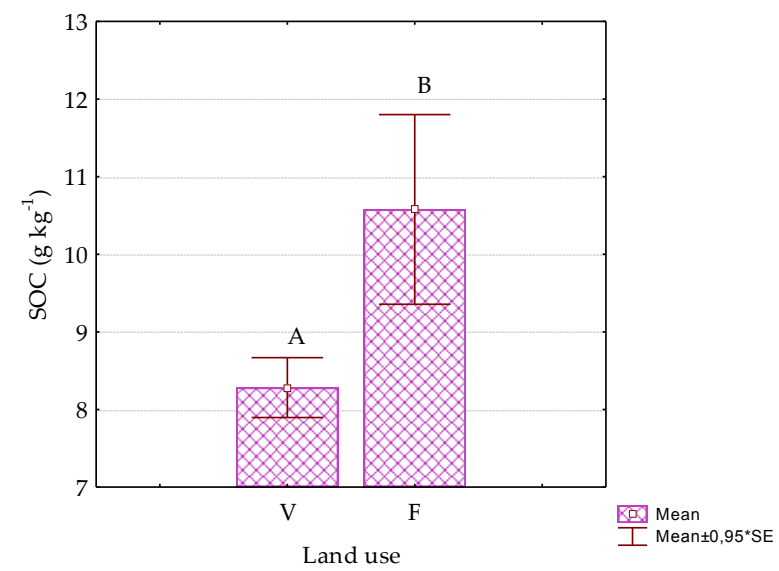

Figure 9. Effect of land use on soil organic carbon content. Significant differences between soil groups are labeled with different letters, $p<0.01(\mathrm{~N}=60)$. 
Due to the specificities of soils in vineyards, such as limited soil development and their coarse texture and low capacity to protect SOM from binding to soil minerals, these soils are sensitive to degradation [28-30]. In addition, intensive viticulture under conventional cultivation systems is likely to increase the risk of soil degradation in the studied area. Intensive viticulture could lead to the loss of soil fertility, acceleration of soil erosion and SOM mineralization and increases in $\mathrm{CO}_{2}$ emissions [59,70,71]. Soil tillage affects soil respiration, temperature, water content, $\mathrm{pH}$, oxidation-reduction potential and the soil ecology $[6,61]$. In particular, it enhances the microbial biomass turnover and, in turn, the short-term $\mathrm{CO}_{2}$ evolution by improving soil aeration, increasing the contact between soil and crop residues and exposing organic matter to microbial attack [17].

Similar results were obtained in wine-producing regions in the state of Santa Catarina, Brazil [65]. In the study by Gatullo et al. [72], the SOC content in a table grape vineyard in southern Italy was $2.86 \mathrm{~g} \mathrm{~kg}^{-1}$. Similar results were recorded by Doğan and Gülser [54] in a soil study in the Menderes district of Izmir, Turkey, where the SOC content was in the range of 2.70-14.91 $\mathrm{g} \mathrm{kg}^{-1}$. Zhou et al. [4] concluded that land use is the main SOC change driver.

Previous studies in Serbian soils have shown that land use is an important factor in SOC variability. Manojlovic et al. [21] observed a significantly higher SOC content in forest land (0-20 cm depth) compared to agricultural land. Vidojević [55] stated that the largest reserves of organic carbon are in forest soil $\left(27.8 \mathrm{~g} \mathrm{~kg}^{-1}\right)$, while they are significantly lower $\left(15.80 \mathrm{~g} \mathrm{~kg}^{-1}\right)$ in agricultural land. In the study by Antonović and Mrvić [73], the average SOC content in forests was $15.20 \mathrm{~g} \mathrm{~kg}^{-1}$. The SOC in vineyards was lower, $12.91 \mathrm{~g} \mathrm{~kg}^{-1}$.

\subsection{Effects of Land Use on SOC Across Topographic Positions}

The interaction between topographic position and land use had a significant effect on SOC (Figure 10). The SOC contents of forest land were significantly higher at the upper position $\left(17.32 \mathrm{~g} \mathrm{~kg}^{-1}\right)$ than that at the middle $\left(9.56 \mathrm{~g} \mathrm{~kg}^{-1}\right)$ and lower positions $\left(8.46 \mathrm{~g} \mathrm{~kg}^{-1}\right)$. However, SOC contents in vineyards were not significantly different across topographic positions. At the lower positions in vineyards, SOC ranged from $3.95 \mathrm{~g} \mathrm{~kg}^{-1}$ to $12.24 \mathrm{~g} \mathrm{~kg}^{-1}$, with an average value of $8.09 \mathrm{~g} \mathrm{~kg}^{-1}$. At the middle positions, the SOC content ranged from 4.17 to $12.47 \mathrm{~g} \mathrm{~kg}^{-1}$, with a mean value of $9.20 \mathrm{~g} \mathrm{~kg}^{-1}$. At the upper topographic position in vineyards, the SOC content ranged from $3.88 \mathrm{~g} \mathrm{~kg}^{-1}$ to $15.49 \mathrm{~g} \mathrm{~kg}^{-1}$, with an average value of $8.17 \mathrm{~g} \mathrm{~kg}^{-1}$.

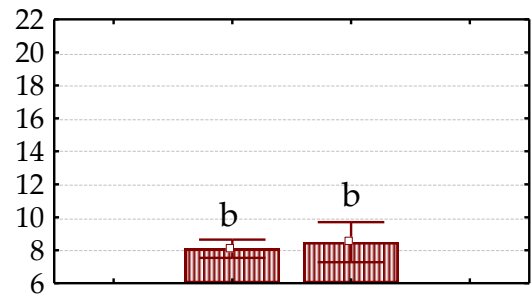

V

$<350$ m a.s.1.

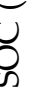

๖ 20

22
20
18
16

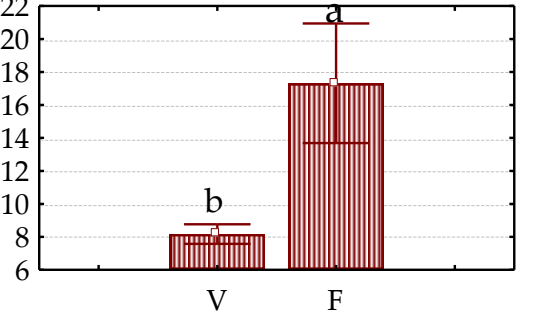

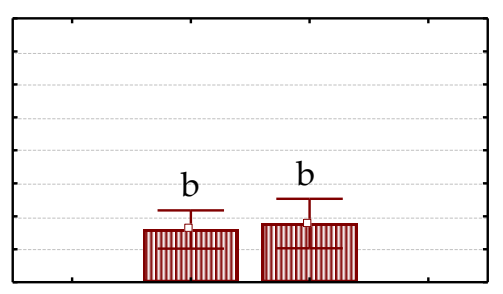

$\mathrm{V}$

350-450 m a.s.1.

㽪l Mean I Mean $\pm 0,95^{*}$ SE

$>450 \mathrm{~m}$ a.s.1.

Figure 10. Effects of land use on SOC across topographic positions. Significant differences between soil groups are labeled with different letters, $p<0.05(\mathrm{~N}=60)$. V-vineyard, $\mathrm{F}$-forest. 
Unlike forests, which have less human interference, agricultural land is often disturbed by soil management. Variations in the SOC content at the same altitude and with the same soil type were primarily due to the different approaches of winegrowers to vineyard fertilization and tillage (see Section 3.6). Some winegrowers avoid using organic fertilizers because they fear there will be negative effects on the quality of the grapes (extended period of grape ripening, low sugar and high acid content). Furthermore, there is also a higher risk of SOC being leached from upper to lower topographic positions in agricultural land compared to forests. Similar results were obtained by Dortzbach et al. [74]. Their study found that the irregular spatial distribution of SOC in the vineyard soils was significantly influenced by management practices and soil disturbance, in addition to altitude and climatic factors. Furthermore, Abebe et al. [65] observed irregularities in the spatial distribution of SOC in vineyard soils.

\subsection{The Influence of Soil Management on SOC}

Figure 11 shows the SOC content, which depended on the management practice, in the topsoil and subsoil of vineyards. The effects of soil type and location on the SOC of vineyards were not significant in our study. Vineyards, in which deep tillage was performed along with the application of organic amendments, had a higher average SOC content in subsoil in comparison to vineyards in which tillage was performed at depths of $30-40 \mathrm{~cm}$. There was no difference in the surface layer.

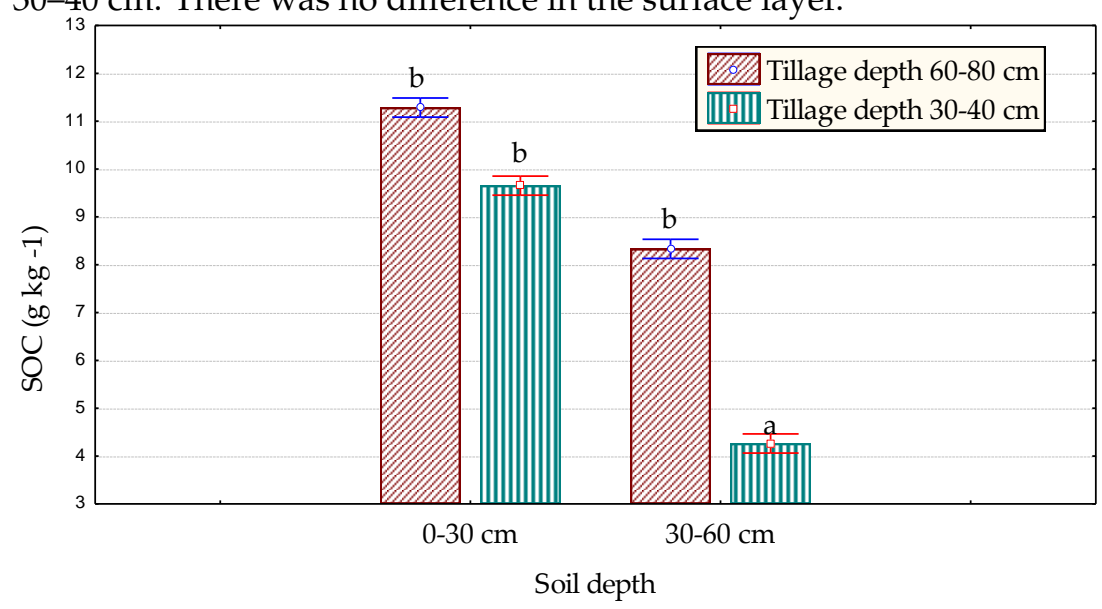

Figure 11. Soil organic carbon (SOC) content in soil layers of vineyards for different tillage depths $(\mathrm{N}=60)$. Significant differences between soil groups are labeled with different letters, $p<0.05$.

The SOC content in the subsoil of deeply tilled vineyards was similar to the value in the subsoil of forest land. Deep tillage $(60-80 \mathrm{~cm})$ has led to deep placement of organic amendments. This practice shows high potential for SOC preservation in the deeper soil layer and for prevention of carbon loss from the surface layer. Subsoil has high potential for the storage of additional soil organic carbon because of the large number of unsaturated mineral surfaces and environmental conditions that impede SOC decomposition, e.g., a more constant moisture and temperature regime or oxygen limitation [75]. Subsoiling can break compacted hardpan layers and it reduces soil strengths and improves water use efficiencies [75-77]. Similar results have been obtained by other authors. According to Liu et al. [16], deep tillage (subsoiling) increased SOC and N compared to conventional tillage. Cervantes et al. [78] stated that after the deep plowing, the layer of the deeply plowed fields accumulated $0.4 \pm 0.1 \mathrm{Mg} \mathrm{SOC} \mathrm{ha-1} \mathrm{yr}^{-1}$ on average. In the study by Shen et al. [79], subsoiling was found to increase aggregate-associated organic carbon, dry matter and maize yield on the North China Plain.

\subsection{SOC and Soil Compaction}

In our study, in the surface horizon $(0-30 \mathrm{~cm})$ on all plots (Figure 12, line a), the compaction was within the optimal values. At a depth of $30 \mathrm{~cm}$, the compaction went 
beyond the optimum range, as it entered the range of moderately compacted soil up to the fiftieth centimeter, where it continued to grow. In some plots, a significant increase in penetrometric resistance or soil compaction at the depth of tillage could be observed (Figure 12, line c), which can negatively affect the growth and development of the root system of plants. Also, the presence of a soil layer with low permeability has resulted in the the top soil layer being more prone to saturation with water. The top soil layer is thus at risk of causing landslides. In contrast, individual plots were characterized by optimum values throughout the entire soil layer in which the plant root system had already developed (Figure 12, line b). Increased soil compaction has a very unfavorable effect on both soil and plants [46]. Soil compaction can induce or accelerate other soil degradation processes, such as erosion or landslides. Compaction reduces the infiltration rate, which increases run-off in sloping [80].

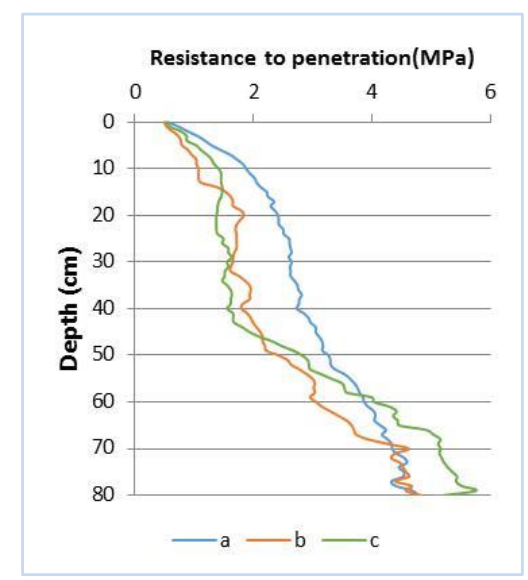

Figure 12. Penetrometric resistance of the tested soil: (a) average value for all plots; (b) Jasenovik locality—haplic vertisol (ochric), VR-ha-oh; (c) Malča locality—haplic vertisol, VR-ha-oh.

Heavy mechanization, extensive cultivation activities-especially if performed under unfavorable soil moisture conditions-and a trend of decreasing organic matter content in agricultural soils increase soil compaction and disturb the water, air and temperature regime.

Soil structure can be improved by increasing soil organic matter [81] and reducing the soil's susceptibility to compaction, erosion and landslides [82,83]. Increases in organic matter can reduce compactibility by increasing resistance to deformation and/or increasing elasticity (rebound effects) [84]. In our study, a significant negative correlation $(-0.53)$ was found between the SOC content and soil compaction, expressed through penetrometric soil resistance. Similar results were obtained in the study by Vasin et al. [85]. Compactibility is sensitive to even quite small changes in the amount of organic matter. These observations have important implications for the improvement of soil management in order to avoid over-compaction problems in crop production.

\section{Conclusions}

The amount of organic carbon in soil and its spatial distribution depend on the land use, soil depth, altitude and management practices, as well as the interaction between land use and topographic position. Land use proved to be an important factor influencing SOC distribution. Due to specific soil properties in vineyards and the conventional land cultivation and specific fertilization strategies used, vineyards contained less SOC than forest land. The effect of topographic position was significant. The distribution of SOC in forest soils was influenced by altitude. At higher altitudes, SOC accumulation was higher due to lower temperatures and increased levels of soil moisture. At lower positions, higher soil temperatures led to a significant decrease in SOC content. The spatial distribution of organic carbon in the vineyards was not dependent on altitude, but most likely resulted 
from different soil management practices. Deep tillage at 60-80 cm, along with application of organic amendments, has high potential for the preservation of SOC in the deeper soil layer and for the prevention of carbon loss from the surface layer. Continuous tillage in vineyards at constant depths has led to the formation of a layer with low permeability. Increases in SOC content, i.e., organic matter, reduce soil compaction and lower the risk of erosion and landslides.

Knowledge of soil carbon distribution as a function of topographic position, land use and management practice is important for sustainable soil management and climate change mitigation. Systematic monitoring and more efficient soil management should be considered for the improvement of SOC status.

Supplementary Materials: The following are available online at https://www.mdpi.com/article/10.3 390 / agronomy11071438/s1, Figure S1. Some of the observed vineyards in the vineyard region of Nišs.

Author Contributions: Conceptualization, S.J. and J.N.; methodology, S.J., J.N. and V.P.; formal analysis, S.J., M.Ž. and V.P.; investigation, S.J., J.N., V.P., M.Ž., S.M., B.B., S.V., V.K., G.D. and J.V.; data curation, S.J., M.Ž., B.B., V.P., S.V.; V.K., G.D. and S.M.; writing—original draft preparation S.J.; review and editing, J.N.; writing-review and editing S.J. All authors have read and agreed to the published version of the manuscript.

Funding: This research is part of the project "Soil fertility control and content of hazardous and harmful substances in the soil under the vineyards of the Nis region" funded by Ministry of Agriculture and Environmental Protection, Directorate for Agricultural Land. A part of this research was supported by the Ministry of Education, Science and Technological Development of the Republic of Serbia, grant no. 451-03-68/2021-14/200032 and grant no. 451-03-9/2021-14/200007.

Institutional Review Board Statement: Not applicable.

Informed Consent Statement: Not applicable.

Data Availability Statement: Not applicable.

Acknowledgments: The authors are thankful to Darko Jakšić from the Centre for Viticulture and Oenology, Belgrade, for his valuable input with detailed data and terroir descriptions of the Niš vineyard region.

Conflicts of Interest: The authors declare no conflict of interest. The funders had no role in the design of the study; in the collection, analyses, or interpretation of data; in the writing of the manuscript, or in the decision to publish the results.

\section{References}

1. Zhang, J.; Wang, X.; Wang, J. Impact of land use change on profile distributions of soil organic carbon fractions in the Yanqi Basin. Catena 2014, 115, 79-84. [CrossRef]

2. Martin, D.; Lal, T.; Sachdev, C.B.; Sharma, J.P. Soil organic carbon storage changes with climate change, landform and land use conditions in Garhwal hills of the Indian Himalayan mountains. Agric. Ecosyst. Environ. 2010, 138, 64-73. [CrossRef]

3. Lal, R. Sequestering Carbon in Soils of Agro-Ecosystems. Food Policy 2011, 36, S33-S39. [CrossRef]

4. Zhou, Y.; Hartemink, A.; Shi, Z.; Liang, Z.; Lu, Y. Land use and climate change effects on soil organic carbon in North and Northeast China. Sci. Total Enivorn. 2019, 647, 1230-1238. [CrossRef] [PubMed]

5. Batjes, N.H. Soil Property Values for Broad-Scale Modelling (WISE30sec) with Estimates of Global Soil Carbon Stocks. Geoderma 2016, 269, 61-68. [CrossRef]

6. Scharlemann, J.P.W.; Tanner, E.V.J.; Hiederer, R.; Kapos, V. Global Soil Carbon: Understanding and Managing the Largest Terrestrial Carbon Pool. Carbon Manag. 2014, 5, 81-91. [CrossRef]

7. Lal, R. Food security impacts of the "4 per Thousand" initiative. Geoderma 2020, 374, 114427. [CrossRef]

8. Wang, D.; Liu, Y.; Wu, G.L.; Ding, L.M.; Yang, Z.; Hao, H.M. Effect of rest-grazing management on soil water and carbon storage in an arid grass-land. J. Hydrol. 2015, 527, 754-760.

9. Jobbágy, E.G.; Jackson, R.B. The vertical distribution of soil organic carbon and its relation to climate and vegetation. Ecol. Appl. 2000, 10, 423-436. [CrossRef]

10. IPCC. Summary for policy makers. In Climate Change 2013: The Physical Science Basis, Contribution of Working Group I to the Fifth Assessment Report of the Intergovernmental Panel on Climate Change; Stocker, T., Qin, D., Plattner, G., Tignor, M., Allen, S., Boschung, J., Nauels, A., Xia, Y., Bex, V., Midgley, P., Eds.; Cambridge University Press: Cambridge, UK; New York, NY, USA, 2013; pp. 1-30. 
11. Wiesmeier, M.; Urbanski, L.; Hobley, E.; Lang, B.; von Lützow, M.; Marin-Spiotta, E.; van Wesemael, B. Soil Organic Carbon Storage as a Key Function of Soils-A Review of Drivers and Indicators at Various Scales. Geoderma 2019, 333, 149-162. [CrossRef]

12. Don, A.; Schumacher, J.; Freibauer, A. Impact of tropical land-use change on soil organic carbon stocks-A meta-analysis. Glob. Chang. Biol. 2011, 17, 1658-1670. [CrossRef]

13. Guo, L.B.; Gifford, R.M. Soil carbon stocks and land use change: A meta-analysis. Glob. Chang. Biol. 2002, 8, 345-360. [CrossRef]

14. Wang, Y.; Fu, B.; Lü, Y.; Chen, L. Effects of vegetation restoration on soil organic carbon sequestration at multiple scales in semi-arid Loess Plateau, China. Catena 2011, 85, 58-66. [CrossRef]

15. Deng, L.; Zhu, G.; Tang, Z.; Shannguan, Z. Global patterns of the effects of land-use changes on soil carbon stocks. Glob. Ecol. Conserv. 2016, 5, 127-138. [CrossRef]

16. Liu, X.; Liu, J.; Xing, B.; Herbert, S.J.; Meng, K.; Han, X.; Zhang, X. Effects of Long-Term Continuous Cropping, Tillage, and Fertilization on Soil Organic Carbon and Nitrogen of Black Soils in China. Commun. Soil Sci. Plant Anal. 2005, 36, 1229-1239. [CrossRef]

17. Beare, M.H.; Hendrix, P.F.; Cabrera, M.L.; Coleman, D.C. Aggregate-Protected and Unprotected Organic Matter Pools in Conventional- and No-Tillage Soils. Soil Sci. Soc. Am. J. 1994, 58, 787-795. [CrossRef]

18. Sun, W.; Zhu, H.; Guo, S. Soil organic carbon as a function of land use and topography on the Loess Plateau of China. Ecol. Eng. 2015, 83, 249-257. [CrossRef]

19. Dessalegn, D.; Beyene, S.; Ram, N.; Walley, F.; Gala, T.S. Effects of topography and land use on soil characteristics along the toposequence of Ele watershed in southern Ethiopia. Catnea 2014, 115, 47-54. [CrossRef]

20. Dialynas, Y.G.; Bastola, S.; Bras, R.L.; Billings, S.A.; Markewitz, D.; Richter, D.d. Topographic variability and the influence of soil erosion on the carbon cycle. Glob. Biogeochem. Cycles 2016, 30, 644-660. [CrossRef]

21. Manojlović, M.; Čabilovski, R.; Sitaula, B. Soil Organic Carbon in Serbian Mountain Soils: Effects of Land Use and Altitude. Pol. J. Environ. Stud. 2011, 20, 977-986.

22. Bot, A.; Benites, J. The Importance of Soil Organic Matter Key to Drought-Resistant Soil and Sustained Food Production; FAO: Rome, Italy, 2005.

23. Wischmeier, W.H.; Mannering, J. Relation of soil properties to its erodibility. Soil Sci. Soc. Amer. Proc. 1969, 33, 131-137. [CrossRef]

24. Ristić, R.; Milošević, D. Hidrologija Bujičnih Tokova; Šumarski Fakultet: Belgrade, Serbia, 2011.

25. Perović, V.; Jakšić, D.; Jaramaz, D.; Koković, N.; Čakmak, D.; Mitrović, M.; Pavlović, P. Spatio-temporal analysis of land use/land cover change and its effects on soil erosion (Case study in the Oplenac wine-producing area, Serbia). Environ. Monit. Assess. 2018, 190, 675. [CrossRef] [PubMed]

26. Comino, J.R.; Iserloh, T.; Morvan, X.; Malam Issa, O.; Naisse, C.; Keesstra, S.D.; Cerdà, A.; Prosdocimi, M.; Arnáez, J.; Lasanta, T.; et al. Soil Erosion Processes in European Vineyards: A Qualitative Comparison of Rainfall Simulation Measurements in Germany, Spain and France. Hydrology 2016, 3, 6. [CrossRef]

27. Le Bissonnais, Y.; Blavet, D.; De Noni, G.; Laurent, J.-Y.; Asseline, J.; Chenu, C. Erodibility of Mediterranean Vineyard Soils: Relevant Aggregate Stability Methods and Significant Soil Variables. Eur. J. Soil Sci. 2007, 58, 188-195. [CrossRef]

28. Martínez-Casasnovas, J.A.; Concepción Ramos, M. Soil Alteration Due to Erosion, Ploughing and Levelling of Vineyards in North East Spain. Soil Use Manag. 2009, 25, 183-192. [CrossRef]

29. Belmonte, S.A.; Celi, L.; Stahel, R.J.; Bonifacio, E.; Novello, V.; Zanini, E.; Steenwerth, K.L. Effect of Long-Term Soil Management on the Mutual Interaction Among Soil Organic Matter, Microbial Activity and Aggregate Stability in a Vineyard. Pedosphere 2018, 28, 288-298. [CrossRef]

30. Teferi, E.; Bewket, W.; Simane, B. Effects of land use and land cover on selected soil quality indicators in the headwater area of the Blue Nile basin of Ethiopia. Environ. Monit. Assess. 2016, 188, 83. [CrossRef] [PubMed]

31. Solomon, D.; Lehmann, J.; Zech, W. Land use effects on soil organic matter properties of chromic luvisols in semi-arid northern Tanzania: Carbon, nitrogen, lignin and carbohydrates. Agric. Ecosyst. Environ. 2000, 78, 203-213. [CrossRef]

32. Jakšić, S.; Ninkov, J.; Milić, S.; Vasin, J.; Banjac, D.; Jakšić, D.; Živanov, M. The State of Soil Organic Carbon in Vineyards as Affected by Soil Types and Fertilization Strategies (Tri Morave Region, Serbia). Agronomy 2021, 11, 9. [CrossRef]

33. Ivanišević, D.; Jakšić, D.; Korać, N. Vineyard Atlas; Republican Bureau of Statistics: Belgrade, Serbia, 2015.

34. Jakšić, D.; Petrović, V. Some important properties of the terroir of the Vineyard region of Niš. In Soil Properties of the Vineyard Region of Niš; Ninkov, J., Ed.; Institute of Field and Vegetable Crops: Novi Sad, Serbia, 2017.

35. Nakalamić, A.; Marković, N. Opšte Vinogradarstvo; Poljoprivredni Fakultet Beograd; Zadužbina Svetog Manastira Hilandara: Belgrade, Serbia, 1993.

36. Tonietto, J.; Carbonneau, A. A multicriteria climatic classification system for grape-growing regions worldwide. Agric. For. Meteorol. 2004, 124, 81-97. [CrossRef]

37. Vasin, J.; Živanov, M. Soil classification in the Vineyard region of Niš. In Soil Properties of the Vineyard Region of Niš; Ninkov, J., Ed.; Institute of Field and Vegetable Crops: Novi Sad, Serbia, 2017.

38. ISO/IEC 17025:2017. General Requirements for the Competence of Testing and Calibration Laboratories; ISO: Geneva, Switzerland, 2017.

39. ISO 11464:2006. Soil Quality_Pretreatment of Samples for Physico-Chemical Analysis; Institute for Standardization of Serbia: Belgrade, Serbia, 2006.

40. ISO 10390:2005. Soil Quality—Determination of PH; Institute for Standardization of Serbia: Belgrade, Serbia, 2005. 
41. ISO 10693:1995. Soil Quality-Determination of Carbonate Content_Volumetric Method; Institute for Standardization of Serbia: Belgrade, Serbia, 1995.

42. ISO 10694:1995. Soil Quality—Determination of Organic and Total Carbon after Dry Combustion (Elementary Analysis); Institute for Standardization of Serbia: Belgrade, Serbia, 1995.

43. Van Reeuwijk, L.P. Procedures for Soil Analysis, 6th ed.; ISRIC FAO Technical Paper vol. 9; International Soil Reference and Information Centre Wageningen: Wageningen, The Netherlands, 2002.

44. Wischmeier, W.H.; Smith, D.D. Predicting Rainfall Erosion Losses: A Guide to Conservation Planning; Agriculture Handbook, No 537; USDA/Science and Education Administration; US Government Printing Office: Washington, DC, USA, $1978 ;$ p. 58.

45. Van der Knijff, J.M.; Jones, R.J.A.; Montanarella, L. Soil Erosion Risk Assessment in Italy; EUR 19022 EN; European Soil Bureau: Ispra, Italy, 1999; p. 52.

46. Grimm, M.; Jones, R.J.A.; Rusco, E.; Montanarella, L. Soil Erosion Risk in Italy: A Revised USLE Approach; EUR, EN; Office for Official Publications of the European Communities: Luxembourg, 2003; p. 23.

47. Desmet, P.J.J.; Govers, G. A GIS procedure for automatically calculating the USLE LS factor on topographically complex landscape units. J. Soil Water Conserv. 1996, 51, 427-433.

48. OECD. Environmental Performance of Agriculture in OECD Countries; Organisation for Economic Co-operation and Development (OECD): Paris, France, 2008.

49. Ninkov, J. Karakterizacija Zemljišta Niškog Vinogradarskog Rejona; Institute of Field and Vegetable Crops: Novi Sad, Serbia, 2014.

50. Leake, S. Vineyard Soil Management; Sydney Environmental \& Soil Laboratory Pty Ltd.: Sydney, Australia, 1999.

51. White, R.E. Soils for Fine Wines; Oxford University Press: New York, NY, USA, 2003.

52. Gücüyen, A. Manisa ili ve Çevresinde Bağcılıkta Mekanizasyon Durumu, Sorunları ve iyi Tarım Uygulamalarına Yönelik Çözüm Önerileri; Ege Üniversitesi Fen Bilimleri Enstitüsü: İzmir, Turkey, 2007; p. 146. (In Turkish)

53. Kosmas, C.; Danalatos, N.; Cammeraat, L.H.; Chabart, M.; Diamantopoulos, J.; Farand, R.; Gutierrez, L.; Jacob, A.; Marques, H.; Martinez-Fernandez, J.; et al. The effect of land use on runoff and soil erosion rates under Mediterranean conditions. Catena 1997, 29, 45-59. [CrossRef]

54. Doğan, B.; Gülser, C. Assessment of Soil Quality for Vineyard Fields: A Case Study in Menderes District of Izmir, Turkey. Eurasian J. Soil Sci. 2019, 8, 176-183. [CrossRef]

55. Vidojević, D. Estimation of Soil Organic Matter in the Soils of Serbia; Faculty of Agriculture: Novi Sad, Serbia, 2015.

56. Smith, W.N.; Desjardins, R.L.; Pattey, E. The Net Flux of Carbon from Agricultural Soils in Canada 1970-2010. Glob. Chang. Biol. 2000, 6, 557-568. [CrossRef]

57. Gardi, C.; Sconosciuto, F. Evaluation of carbon stock variation in Northern Italian soils over the last 70 years. Sustain. Sci. 2007, 2, 237-243. [CrossRef]

58. Morari, F.; Lugato, E.; Berti, A.; Giardini, L. Long-Term Effects of Recommended Management Practices on Soil Carbon Changes and Sequestration in North-Eastern Italy. Soil Use Manag. 2006, 22, 71-81. [CrossRef]

59. Novara, A.; Minacapilli, M.; Santoro, A.; Rodrigo-Comino, J.; Carrubba, A.; Sarno, M.; Venezia, G.; Gristina, L. Real Cover Crops Contribution to Soil Organic Carbon Sequestration in Sloping Vineyard. Sci. Total Environ. 2019, 652, 300-306. [CrossRef] [PubMed]

60. Robinson, C.A.; Cruse, R.M.; Kohler, K.A. Soil management. In Sustainable Agricultural Systems; Hatfield, J.L., Karlen, D.L., Eds.; Lewis Publishers: Boca Raton, FL, USA, 1994; pp. 109-134.

61. Sims, Z.R.; Nielsen, G.A. Organic carbon in Montana soils as related to clay content and climate. Soil Sci. Soc. Am. 1986, 50, 1269. [CrossRef]

62. Dai, W.; Huang, Y. Relation of soil organic matter concentration to climate and altitude in zonal soils of China. Catena 2006, 65, 87. [CrossRef]

63. Trumbore, S.E.; Vitousek, P.M.; Amundson, R.R. Rapid exchange between soil carbon and atmospheric carbon dioxide driven by temperature change. Science 1996, 272, 393. [CrossRef]

64. Fang, H.; Ji, B.; Deng, X.; Ying, J.; Zhou, G.; Shi, Y.; Xu, L.; Tao, J.; Zhou, Y.; Li, C.; et al. Effects of topographic factors and aboveground vegetation carbon stocks on soil organic carbon in Moso bamboo forests. Plant Soil 2018, 433, 363-376. [CrossRef]

65. Abebe, G.; Tsunekawa, A.; Haregeweyn, N.; Takeshi, T.; Wondie, M.; Adgo, E.; Masunaga, T.; Tsubo, M.; Ebabu, K.; Berihun, M.L.; et al. Effects of Land Use and Topographic Position on Soil Organic Carbon and Total Nitrogen Stocks in Different Agro-Ecosystems of the Upper Blue Nile Basin. Sustainability 2020, 12, 2425. [CrossRef]

66. Zheng, X.Y.; Liu, M.Z.; Zhao, X.; Li, Y.; Zhao, W.; Li, A.; Chen, S.; Chen, S.; Han, X.; Huang, J. Topography and grazing effects on storage of soil organic carbon and nitrogen in the northern China grasslands. Ecol. Indic. 2018, 93, 45-53. [CrossRef]

67. Schöning, I.; Totsche, K.U.; Kögel-Knabner, I. Small Scale Spatial Variability of Organic Carbon Stocks in Litter and Solum of a Forested Luvisol. Geoderma 2006, 136, 631-642. [CrossRef]

68. Rhanor, T. Topographic Position and Land Cover Effects on Soil Organic Carbon Distribution of Loess-Veneered Hillslopes in the Central United States; Southern Illinois University: Carbondale, IL, USA, 2013.

69. Jendoubi, D.; Liniger, H.; Speranza, C.I. Impacts of land use and topography on soil organic carbon in a Mediterranean landscape (north-western Tunisia). Soil 2019, 5, 239-251. [CrossRef]

70. Napoli, M.; Dalla Marta, A.; Zanchi, C.A.; Orlandini, S. Assessment of Soil and Nutrient Losses by Runoff under Different Soil Management Practices in an Italian Hilly Vineyard. Soil Tillage Res. 2017, 168, 71-80. [CrossRef] 
71. Rodrigo-Comino, J. Five Decades of Soil Erosion Research in 'Terroir'. The State-of-the-Art. Earth-Sci. Rev. 2018, $179,436-447$. [CrossRef]

72. Gattullo, C.E.; Mezzapesa, G.N.; Stellacci, A.M.; Ferrara, G.; Occhiogrosso, G.; Petrelli, G.; Castellini, M.; Spagnuolo, M. Cover Crop for a Sustainable Viticulture: Effects on Soil Properties and Table Grape Production. Agronomy 2020, 10, 1334. [CrossRef]

73. Antonović, G.; Mrvić, V. Zemljišta Sliva Nišave; Institute for Soil Science: Belgrade, Serbia, 2018.

74. Dortzbach, D.; Assunção, S.A.; Pereira, M.G.; Carvalho da Silva, E. Fractions of soil organic matter in the vineyards of altitude regions in Santa Catarina. Ciênc. Agrárias Londrina 2017, 38, 1799-1812. [CrossRef]

75. Wang, Y.X.; Chen, S.P.; Zhang, D.X.; Yang, L.; Cui, T.; Jing, H.R.; Li, Y.H. Effects of subsoiling depth, period interval and combined tillage practice on soil properties and yield in the Huang-Huai-Hai Plain, China. J. Integr. Agric. 2020, 19, 1596-1608. [CrossRef]

76. Wang, S.L.; Wang, H.; Hafeez, M.B.; Zhang, Q.; Yu, Q.; Wang, R.; Wang, X.; Li, J. Notillage and subsoiling increased maize yields and soil water storage under varied rainfall distribution: A 9-year site-specific study in a semi-arid environment. Field Crop. Res. 2020, 255, 10786. [CrossRef]

77. Pikul, J.L., Jr.; Aase, J.K. Water Infiltration and storage affected by subsoiling and subsequent tillage. Soil Sci. Soc. Am. J. 2003, 67, 859-866. [CrossRef]

78. Cervantes, V.A.; Don, A.; Well, R.; Schneider, F.; Nieder, R. Deep ploughing mineral soils for SOC sequestration. In Global Symposium on Soil Organic Carbon; FAO: Rome, Italy, 2017.

79. Shen, Y.; Zhang, T.; Cui, J.; Chen, S.; Han, H.; Ning, T. Subsoiling increases aggregate-associated organic carbon, dry matter, and maize yield on the North China Plain. Peer J. 2021, 9, e11099. [CrossRef] [PubMed]

80. Scharlemann, J.; Hiederer, R.; Kapos, V. Global Map of Terrestrial Soil Organic Carbon Stocks; UNEP-WCMC; EU-JRC: Cambridge, UK, 2009.

81. Novara, A.; Favara, V.; Novara, A.; Francesca, N.; Santangelo, T.; Columba, P.; Chironi, S.; Ingrassia, M.; Gristina, L. Soil Carbon Budget Account for the Sustainability Improvement of a Mediterranean Vineyard Area. Agronomy 2020, 10, 336. [CrossRef]

82. Kuhn, N.J. Erodibility of soil organic matter: Independence of organic matter resistant to interrill erosion. Earth Surf. Proc. Land 2007, 32, 794-802. [CrossRef]

83. Guerra, A. The effect of organic matter content on soil erosion in simulated rainfall experiements in W. Sussex, U.K. Soil Use Manag. 1994, 10, 60-64. [CrossRef]

84. Soane, B.D. The role of organic matter in soil compactibility: A review of some practical aspects. Soil. Tillage Res. 1990, 16, 179-201. [CrossRef]

85. Vasin, J.; Živanov, M.; Ninkov, J.; Milić, S.; Žeželj, B. Effect of organic farming on soil compaction. In Proceedings of the VI International Scientific Agricultural Symposium “Agrosym 2015”, Jahorina, Bosnia and Herzegovina, 15-18 October 2015; p. 496. 